\title{
THE USE OF SERUM PROTEIN ELECTROPHORESIS IN DIAGNOSIS OF HORSE DISEASES
}

\section{ZASTOSOWANIE ELEKTROFOREZY BIALEK SUROWICY KRWI W DIAGNOSTYCE CHORÓB KONI}

\author{
${ }^{1}$ Department of Animal Genetics and Horse Breeding, Siedlce University of Natural Sciences \\ and Humanities, Poland \\ ${ }^{2}$ Veterinary Diagnostic Laboratory LAB-WET, Warszawa, Poland
}

\begin{abstract}
Streszczenie. Celem pracy było zastosowanie elektroforezy białek surowicy krwi w celu wstępnej oceny stanu fizjologicznego i wykrycia potencjalnych chorób u koni. Elektroforetogram surowicy zdrowych koni charakteryzuje się brakiem strefy prealbumicznej; można zaobserwować sześć różnych pasm: albuminy, $\alpha 1, \alpha 2, \beta 1, \beta 2$, i y-globuliny. U koni wiele stanów patologicznych, takich jak choroby wątroby, wrodzone lub nabyte niedobory odporności, enteropatie i nefropatie związane z utratą białka, zakażenia miejscowe lub układowe, nowotwory i pasożyty, mogą spowodować zmiany we frakcji albumin i w koncentracji globuliny. Również w przypadku babeszjozy koni stężenie w surowicy białka może się znacznie zmienić. Określono zawartość albuminy oraz trzech frakcji globulin wraz z podfrakcjami. $U$ badanych koni ustalono stężenie białka całkowitego i wyznaczono stosunek albumin do wszystkich globulin łącznie (wskaźnik $A / G$ ). Elektroforezę białek surowicy u konia można polecić jako badanie przesiewowe dla jakościowego wykrywania nieprawidłowości w głównych białkach i jako ważne uzupełnienie szczegółowego obliczania białek surowicy.
\end{abstract}

Key words: horse, electrophoresis, serum proteins, disease.

Słowa kluczowe: koine, elektroforeza, białka surowicy, choroby.

\section{INTRODUCTION}

Electrophoresis is one of the basic diagnostic techniques used in analytics. Electrophoretic techniques have been known since the 1930s. The last twenty years have seen an increase in the use of serum protein electrophoresis as a diagnostic test in veterinary patients (Cray et al. 2009; Gerou-Ferrani et al. 2011).

Laboratory evaluation of plasma and serum proteins is a basic test used in animal haematology and biochemistry. Changes in the protein profile commonly occur as secondary changes in numerous diseases, but may be the primary symptom of some. Determination of the serum concentration of proteins often provides vital information which is useful in narrowing down the list of diseases under consideration, and in some cases may reveal a specific disease (Gama et al. 2007; Thrall et al. 2012). Although a final diagnosis is rarely

Corresponding author - Adres do korespondencji: Katarzyna Andraszek, Department of Animal Genetics and Horse Breeding, Siedlce University of Natural Sciences and Humanities, Bolesława Prusa 14, 08-110 Siedlce, Poland, e-mail: katarzyna.andraszek@uph.edu.pl 
based exclusively on protein electrophoresis, it is an excellent method for detecting acute and chronic inflammation and a stimulated humoral immune response (Cray et al. 2009).

Serum protein electrophoresis (a proteinogram) is a basic laboratory test enabling detection of dysproteinaemia and often answering difficult diagnostic questions (Bobilewicz 2005). The proteinogram usually yields six fractions. These include the largest homogenous fraction of albumins and the remaining fractions representing globulins $\alpha 1, \alpha 2, \beta 1, \beta 2$ and $\gamma$, which have the greatest diagnostic significance. Individual fractions consist of different specific proteins with a similar charge and electrophoretic mobility, but with a different structure and biological function (Bobilewicz 2005; Giot 2010; Jania and Andraszek 2016).

Albumins, which account for about $70 \%$ of plasma proteins, stabilize osmotic pressure in the blood and also play a role in transport. A decrease in the content of albumins may lead to proteinuria or exudative enteropathy. Hypoalbuminemia may also result from malnutrition, burns, liver failure, or cancer. An increase in albumin content may signal dehydration (O'Connell et al. 2005). A decrease in the a1-globulin fraction may result from malnutrition or liver failure (Keren 2003; O'Connell et al. 2005). An elevated a1-globulin level is usually due to an increase in acute phase proteins occurring during sepsis (Keren 2003; Bobilewicz 2005; O'Connell et al. 2005).

Decreased content of $\alpha 2$-globulins occurs in the case of liver failure, protein loss or intravascular haemolysis, or may be associated with Menkes' or Wilson's diseas. An increase in the a2-globulin fraction is usually caused by inflammation, nephrotic syndrome, Hodgkin's lymphoma, and cholestasis. A reduction in the level of $\beta$-globulins is coupled with a decrease in the concentration of transferrins, which occurs in cases of malnutrition, in oncogenic or autoimmune diseases, in lupus, and in rheumatoid arthritis. An increase in the $\beta$-globulin fraction occurs in iron deficiency, cirrhosis, and multiple myeloma. Low content of $\mathrm{Y}$-globulins is a normal physiological state in neonates, whereas in adults it results from immune disorders caused by chemio- or radiotherapy, immunosuppression, or corticoid use (Bobilewicz 2005; O'Connell et al. 2005; Giot 2010). An increase in V-globulins is typical of chronic inflammation, cancers, AIDS, and autoimmune diseases. In liver failure, polyclonal gammopathy occurs with a characteristic gamma-beta bridge between these two zones (Bobilewicz 2005; Giot 2010).

A serum proteinogram provides significant information on the patient's clinical condition. The greatest importance is ascribed to qualitative determination of individual proteins, which may be supplemented with quantitative determination. A change in albumin or globulin concentration does not always cause detectable changes in total protein concentration. Therefore both the total protein concentration and that of albumins and globulins should be determined. A decreased total protein concentration may be due to reduced content of albumins, globulins, or both of these groups.

Hypoalbuminemia and hypoglobulinemia may be caused by fluid therapy, haemorrhaging or parasites feeding on blood. A reduced concentration of albumins which is not accompanied by a reduced concentration of globulins may be due to liver damage, starvation, or prolonged malnutrition (Thrall et al. 2012), or to the presence of parasites in the digestive tract (Grauer 2005). Impaired absorption or digestion, chronic inflammation, and kidney disease are also causes of reduced serum albumin levels (Crisman and Scarratt 2008). Hypoglobulinemia without hypoalbuminemia leads to failure of passive absorption of immunoglobulins from colostrum. In the case of innate or acquired immune deficiency associated with B lymphocytes 
and plasma cells, this results in a reduced concentration of gamma globulins and sometimes total globulins (Petersen et al. 2004). The gamma globulin fraction consists of various classes of immunoglobulins. An increase in the concentration of this fraction is called gammopathy. It may be mono- or polyclonal, which can be distinguished by observing the electropherogram (Yamada et al. 2005). The conditions most often responsible for polyclonal gammopathy include chronic inflammation, antigen stimulation, liver disease, lymphomas, or lymphatic leukaemia (Patel et al. 2005; Giori et al. 2011).

The aim of the study was to use serum protein electrophoresis for a preliminary evaluation of the physiological condition of horses and detection of potential diseases.

\section{MATERIAL AND METHODS}

The study was carried out according to the guidelines of the III Ethical Committee in Warszawa.

The material for the study was the peripheral blood of five mares and five geldings. All of the horses were of similar age and kept in similar conditions. Blood was taken twice: after the pasture season (end of November 2015) and before the pasture season (end of May 2016). Blood in the amount of $7 \mathrm{ml}$ was collected from the jugular vein into sterile test tubes with no coagulant. Immediately after collection the blood was centrifuged to isolate the serum, in which protein fractions were determined. The serum content of albumins and three globulin fractions with their subfractions were determined. The total protein concentration and the ratio of albumins to total globulins $(A / G)$ were determined.

Native electrophoresis of serum proteins was performed with an SAS-MX Serum Protein SB kit by Helena Biosciences, used to separate proteins on agarose gels. Serum samples were diluted in TRIS/Barbital buffer to obtain a protein concentration of about $15 \mathrm{~g} / \mathrm{l}$. Each sample was applied to agarose gel in the amount of $3 \mathrm{ul}$ and left for 4 min for adsorption. Separation was conducted for 25 minutes at a constant voltage of $80 \mathrm{~V}$. Next the gel was dried at $60-70^{\circ} \mathrm{C}$ for $5-10 \mathrm{~min}$ and immersed in a solution of Acid Blue for $10 \mathrm{~min}$. Then the gel was immersed in a destaining solution twice for 2 minutes each time. The gel was dried and scanned, and densitometric analysis was performed with Platinum gel analysis software. The results were presented in tables with reference values for comparison.

\section{RESULTS}

In accordance with the aim of the experiment, electrophoresis of the serum proteins of ten horses was performed during two periods: at the end of the pasture season (November) and before the start of the new pasture season (end of May). The content of albumin and three fractions of globulins and their subfractions were determined. The total protein concentration was established and the ratio of albumin to all globulins combined (the A/G ratio) was calculated. The results of the analysis of the electropherograms of all horses are presented in Table 1 , and the serum protein electropherograms are presented in Fig. 1 and Fig. 2.

The lowest level for the albumin fraction $(27.71 \mathrm{~g} / \mathrm{l})$ was noted in gelding 1 after the autumn-winter season. The albumin concentration was also below reference values in geldings 3 and 4 . In both horses a deficiency was noted after the summer season. The highest albumin content $(41.41 \mathrm{~g} / \mathrm{l})$, above the reference values, was noted in gelding 5 after the autumn-winter season. Albumins above the norm were also noted in mare 1 after the autumn-winter season. 
Table 1. The result of the analysis of serum protein electropherograms of all horses studied Tabela 1. Wyniki analizy elektroforezy białek surowicy krwi badanych koni

\begin{tabular}{|c|c|c|c|c|c|c|c|c|c|c|c|c|c|c|c|c|c|c|c|c|}
\hline \multirow{3}{*}{$\begin{array}{c}\text { Fraction } \\
\text { Frakcja }\end{array}$} & \multicolumn{20}{|c|}{$\begin{array}{c}\text { Horses } \\
\text { Konie }\end{array}$} \\
\hline & \multicolumn{2}{|c|}{$\begin{array}{c}\text { mare } \\
\text { klacz } 1\end{array}$} & \multicolumn{2}{|c|}{$\begin{array}{c}\text { mare } \\
\text { klacz } 2\end{array}$} & \multicolumn{2}{|c|}{$\begin{array}{c}\text { mare } \\
\text { klacz } 3\end{array}$} & \multicolumn{2}{|c|}{$\begin{array}{c}\text { mare } \\
\text { klacz } 4\end{array}$} & \multicolumn{2}{|c|}{$\begin{array}{c}\text { mare } \\
\text { klacz } 5\end{array}$} & \multicolumn{2}{|c|}{$\begin{array}{c}\text { gelding } \\
\text { wałach } 1\end{array}$} & \multicolumn{2}{|c|}{$\begin{array}{c}\text { gelding } \\
\text { wałach } 2\end{array}$} & \multicolumn{2}{|c|}{$\begin{array}{c}\text { gelding } \\
\text { wałach } 3\end{array}$} & \multicolumn{2}{|c|}{$\begin{array}{c}\text { gelding } \\
\text { wałach } 4\end{array}$} & \multicolumn{2}{|c|}{$\begin{array}{c}\text { gelding } \\
\text { wałach } 5\end{array}$} \\
\hline & $\mathrm{N}$ & $M$ & $\mathrm{~N}$ & $M$ & $\mathrm{~N}$ & $M$ & $\mathrm{~N}$ & $M$ & $\mathrm{~N}$ & $M$ & $\mathrm{~N}$ & $M$ & $\mathrm{~N}$ & $M$ & $\mathrm{~N}$ & $M$ & $\mathrm{~N}$ & $M$ & $\mathrm{~N}$ & $M$ \\
\hline $\begin{array}{l}\text { Albumins } \\
\text { Albuminy }\end{array}$ & 34.93 & $37.58 \mathrm{H}$ & 30.24 & 31.28 & 32.39 & 35.16 & 33.33 & 32.47 & 30.15 & 32.45 & 29.86 & $27.71 \mathrm{~L}$ & 29.88 & 34.71 & $28.96 \mathrm{~L}$ & 29.21 & $28.30 \mathrm{~L}$ & 33.53 & 30.89 & $41.40 \mathrm{H}$ \\
\hline$\alpha 1$ & $1.16 \mathrm{~L}$ & $1.43 \mathrm{~L}$ & $1.28 \mathrm{~L}$ & $1.74 \mathrm{~L}$ & $0.97 \mathrm{~L}$ & $1.28 \mathrm{~L}$ & $1.10 \mathrm{~L}$ & $1.41 \mathrm{~L}$ & $0.98 \mathrm{~L}$ & $1.14 \mathrm{~L}$ & $1.34 \mathrm{~L}$ & $1.63 \mathrm{~L}$ & $1.19 \mathrm{~L}$ & $1.37 \mathrm{~L}$ & $1.41 \mathrm{~L}$ & $1.28 \mathrm{~L}$ & $1.10 \mathrm{~L}$ & $1.48 \mathrm{~L}$ & $0.96 \mathrm{~L}$ & $1.73 \mathrm{~L}$ \\
\hline$\alpha 2$ & $6.30 \mathrm{H}$ & $6.18 \mathrm{H}$ & $7.16 \mathrm{H}$ & $6.72 \mathrm{H}$ & 5.64 & $6.25 \mathrm{H}$ & $7.24 \mathrm{H}$ & $7.13 \mathrm{H}$ & 5.18 & $6.79 \mathrm{H}$ & $6.34 \mathrm{H}$ & $6.44 \mathrm{H}$ & $7.28 \mathrm{H}$ & $6.61 \mathrm{H}$ & 5.33 & 4.85 & $6.36 \mathrm{H}$ & $6.57 \mathrm{H}$ & 5.38 & $7.59 \mathrm{H}$ \\
\hline$\beta 1$ & 3.30 & 3.70 & $5.93 \mathrm{H}$ & $8.33 \mathrm{H}$ & $6.49 \mathrm{H}$ & $9.36 \mathrm{H}$ & $8.23 \mathrm{H}$ & $7.22 \mathrm{H}$ & 4.16 & $4.70 \mathrm{H}$ & $7.86 \mathrm{H}$ & $8.45 \mathrm{H}$ & $6.86 \mathrm{H}$ & $7.56 \mathrm{H}$ & $4.77 \mathrm{H}$ & $4.53 \mathrm{H}$ & $5.16 \mathrm{H}$ & $6.21 \mathrm{H}$ & $6.40 \mathrm{H}$ & $10.20 \mathrm{H}$ \\
\hline$\beta 2$ & $8.89 \mathrm{H}$ & $9.92 \mathrm{H}$ & $5.02 \mathrm{H}$ & 3.04 & $5.46 \mathrm{~L}$ & 3.38 & $5.17 \mathrm{H}$ & $4.81 \mathrm{H}$ & $6.55 \mathrm{H}$ & $6.54 \mathrm{H}$ & $5.71 \mathrm{H}$ & 3.66 & $5.87 \mathrm{H}$ & $2.32 \mathrm{~L}$ & $8.87 \mathrm{H}$ & $6.77 \mathrm{H}$ & $7.15 \mathrm{H}$ & $6.04 \mathrm{H}$ & $5.49 \mathrm{H}$ & 3.77 \\
\hline Y & 7.42 & 10.18 & 11.37 & 13.90 & $9.04 \mathrm{~L}$ & 11.56 & 10.92 & 13.96 & 10.98 & $15.38 \mathrm{H}$ & 10.88 & $16.09 \mathrm{H}$ & $9.92 \mathrm{~L}$ & 11.42 & 10.66 & $9.36 \mathrm{~L}$ & $9.93 \mathrm{~L}$ & 13.17 & 13.88 & $22.30 \mathrm{H}$ \\
\hline $\begin{array}{l}\text { Total } \\
\text { Łącznie } \\
\text { A/G ratio }\end{array}$ & 62.00 & 69.00 & 61.00 & 65.00 & 60.00 & 67.00 & 60.00 & 67.00 & 58.00 & 67.00 & 62.00 & 64.00 & 61.00 & 64.00 & 60.00 & 56.00 & 58.00 & 67.00 & 63.00 & 87.00 \\
\hline $\begin{array}{l}\text { Stosunek } \\
\text { A/G }\end{array}$ & 1.29 & 1.20 & 0.98 & 0.93 & 1.17 & 1.10 & 1.02 & 0.94 & 1.08 & 0.94 & 0.93 & 0.76 & 0.96 & 1.19 & 0.93 & 1.09 & 0.95 & 1.00 & 0.96 & 0.91 \\
\hline
\end{tabular}

$\mathrm{N}$ - end of November - koniec listopada, M - end of May - koniec maja. 

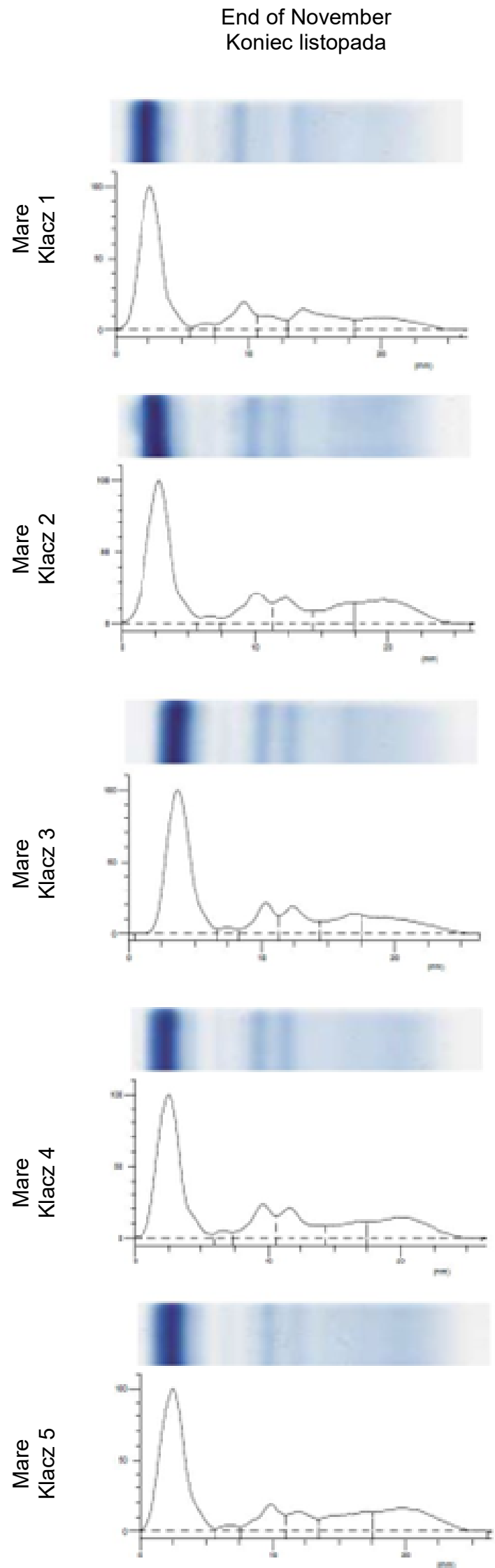

End of May

Koniec maja
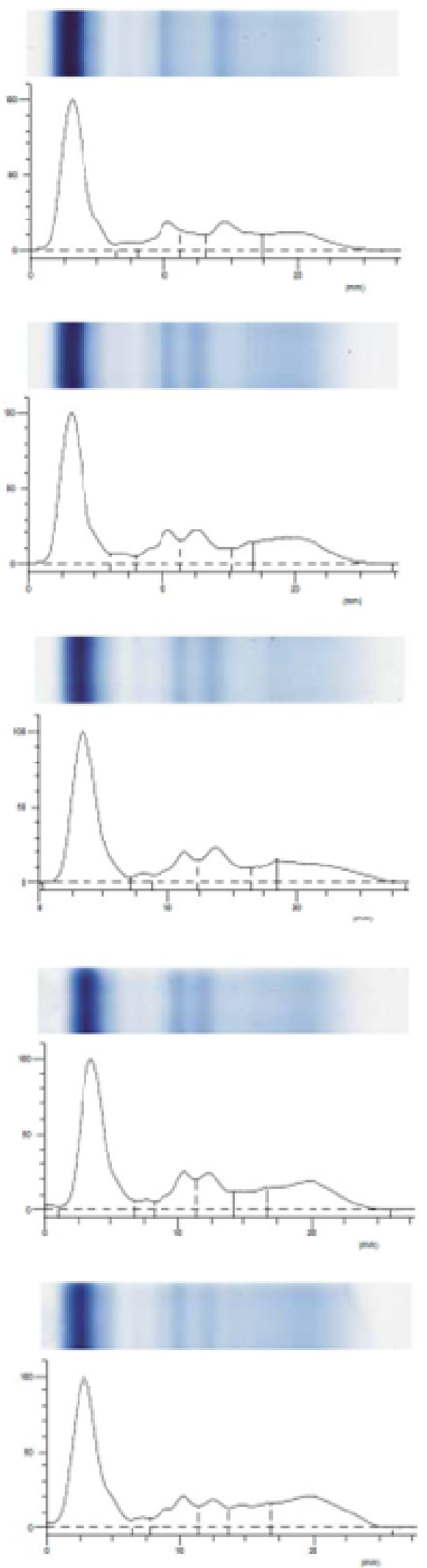

Fig. 1. The serum protein electropherograms of mares studied Ryc. 1. Elektroforeza białek surowicy badanych klaczy 


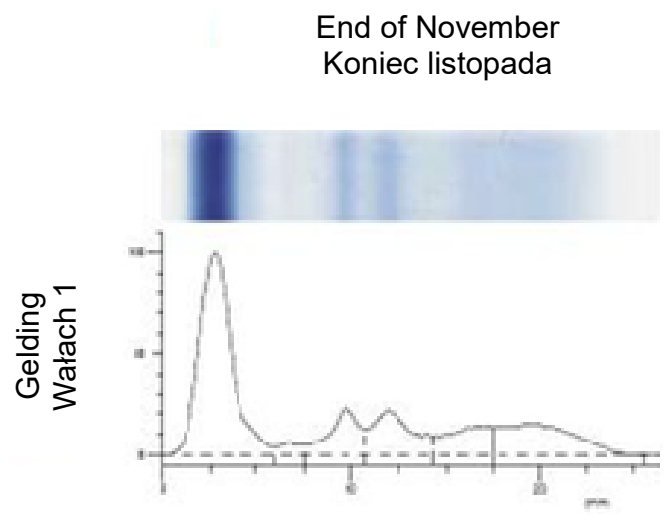

End of May

Koniec maja
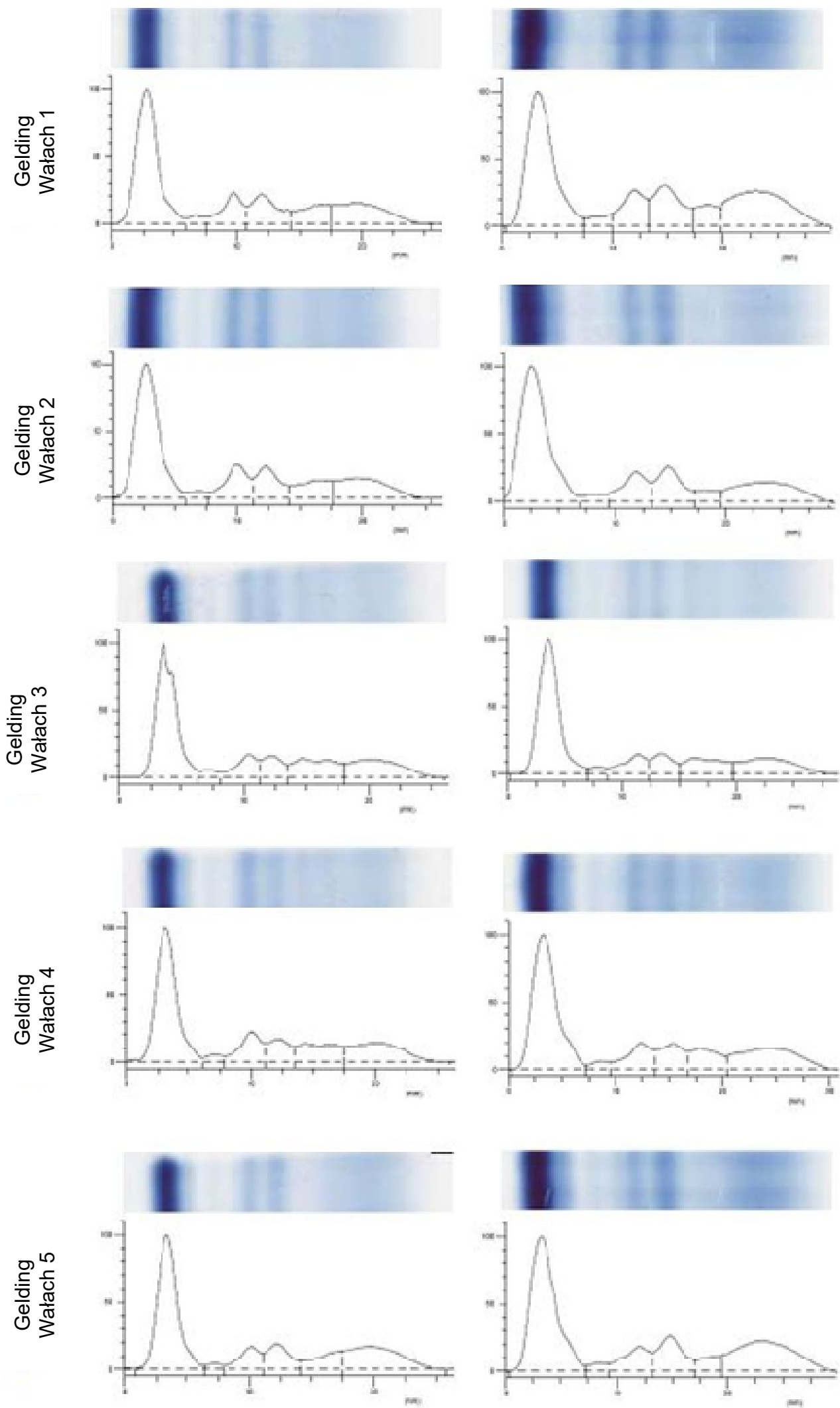

Fig. 2. The serum protein electropherograms of geldings studied Ryc. 2. Elektroforeza białek surowicy badanych wałachów 
Reduced content of the a1 globulin fraction was noted in all horses tested. A tendency towards a slight increase in the concentration of this fraction was observed in the autumnwinter season. Only in gelding 3 did the $\alpha 1$ globulin level drop even further after the autumnwinter period. Despite the increase, the a1 globulin level remained below reference values. The lowest concentration of this fraction $(0.96 \mathrm{~g} / \mathrm{l})$ was noted in gelding 5 after the pasture season. This horse also had highest $\alpha 1$ globulin concentration in the blood $(1.73 \mathrm{~g} / \mathrm{l})$ at the end of May. The level of the $\alpha 2$ globulin fraction was elevated in most of the samples analysed. Normalized values were observed after the summer season in mares 3 and 5 and in gelding 5 . In gelding 3 the $\alpha 2$ globulin level was normal in both seasons. The a 2 globulin level that most exceed the norm $(7.59 \mathrm{~g} / \mathrm{l})$ was observed in gelding 5 after the autumn-winter season and the smallest deviation $(6.18 \mathrm{~g} / \mathrm{l})$ was noted in mare 1 , also after the autumnwinter season. Most of the horses had an elevated $\beta 1$ globulin level. A normal concentration was noted in mare 1 in both periods and in mare 5 after the pasture season. In the remaining horses an increase in the concentration of $\beta 1$ globulins was observed after the autumnwinter season - even further above the norm. An exceptional decrease during the autumnwinter period was noted in gelding 3 . The highest value for $\beta 1$ globulins was noted after the autumn-winter season in gelding $5(10.20 \mathrm{~g} / \mathrm{l})$, while the norm was exceeded to the smallest extent in mare $5(4.70 \mathrm{~g} / \mathrm{l})$. Normative values for the $\beta 2$ globulin fraction were noted in four blood samples collected after the autumn-winter season, from mares 2 and 3 and geldings 1 and 5 . In most of the remaining samples $\beta 2$ globulins were above the norm. In two cases, in mare 3 after the summer season and in gelding 2 at the end of May, the concentration of this globulin fraction decreased. The $y$-globulin fraction in most of the horses was normal. A decreased concentration was noted in mare 3 and in geldings 2 and 4 after the summer season and in gelding 3 after the autumn-winter season. Elevated content of $\beta 2$ globulins was observed in mare 5 and geldings 1 and 5 after the autumn-winter season.

The lowest value for total protein $(56 \mathrm{~g} / \mathrm{l})$ was noted at the end of May in gelding 3, and the highest $(87 \mathrm{~g} / \mathrm{l})$ in gelding 5 , also at the end of May. The A/G ratio was lowest $(0.76)$ at the end of May in gelding 1, and highest (1.29) in mare 1 after the pasture season.

\section{DISCUSSION}

Serum electrophoresis is a common diagnostic laboratory technique in humans and small animals. Nevertheless, despite the fact that it provides useful information on protein fractions, including acute phase proteins which increase immediately after inflammation, and inflammatory diseases frequently occur in horses, serum electrophoresis is not commonly used in equine medicine.

The serum electropherogram of healthy horses is characterized by the lack of a prealbumin zone, and six different bands can be observed: albumin and $\alpha 1-, \alpha 2-, \beta 1-, \beta 2-$, and Y-globulin (Carapeto et al. 2006; Barrera et al. 2010). Many pathological conditions in horses, such as liver disease, innate or acquired immune deficiencies, enteropathies and nephropathies associated with protein loss, local or systemic inflammation, cancers, and parasites can cause changes in the albumin fraction and globulin concentration. The serum protein level can also change significantly in the case of equine babesiosis (Kumar et al. 2002). 
In the literature, the number of studies on the use of serum electrophoresis in equine diagnostics is insufficient. The few analyses deal with quantitative determination of individual proteins or occasionally the subject of infections. One study described in the literature was aimed at quantitative analysis of the concentration of proteins in horse serum using agarose gel electrophoresis and establishment of relative and absolute values for albumins, a1-, $\alpha 2-$, $\beta 1-, \beta 2-$, and $\gamma$-globulins, and the albumin to globulin ratio. Total protein concentration at a level from 51 to $72 \mathrm{~g} / \mathrm{l}$ and clear separation of individual fractions were obtained (albumins and the $\alpha 1-, \alpha 2-, \beta 1-, \beta 2-$, and $y$-globulin fractions were distinct). No significant differences were found between draught horses and thoroughbreds in terms of total protein, albumins, globulins or the $A / G$ ratio; therefore there is no need to establish separate reference ranges for these breeds (Riond et al. 2009; Stachurska et al. 2014).

Serum electrophoresis is also a useful diagnostic technique in some diseases characterized by quantitative and qualitative changes in serum protein, such as acute phase proteins. Increased synthesis of acute phase proteins is associated with acute infection and inflammation. A study by Carapeto et al. (2006) evaluated the effect of gastrointestinal and locomotor disorders in horses. The researchers tested whether the disorders caused an inflammatory reaction sufficient to enable detection of acute phase proteins in serum electrophoresis. The 63 horses tested were assigned to three groups: group I (19 healthy horses), group II (20 horses suffering from inflammatory gastrointestinal diseases) and group III (24 horses suffering from inflammatory locomotor disorders). The results indicated an increase in acute phase proteins only in the case of rapid progression of an inflammatory disorder (Carapeto et al. 2006).

Although acute inflammatory disorders usually cause an increase in certain proteins in the a1-globulin fraction (a1-antitrypsin, a2-macroglobulin, ceruloplasmin, haptoglobin and a1-acid glycoprotein), the group III horses (with locomotor disorders) had chronic inflammatory disorders which could explain the results. Chronic inflammation can be the consequence of many different inflammatory stimuli. In these circumstances an increase in the concentration of acute phase proteins is generally observed. However, this increase is lower than during episodes of acute inflammation or infection (Carapeto et al. 2006). Although some authors report cases of elevated levels of proteins belonging to this region, the literature is not conclusive. Alsemgeest et al. (1994) reported an increase in the serum protein amyloid $A$ in animals with inflammatory disorders, some of which involve the locomotor system. Taira et al. (1992) described certain increases in the haptoglobin level in horses suffering from rhabdomyolysis or in the case of trauma. Fagliari et al. (1998) observed an increase in $\alpha$ - antitrypsin I and II, $\alpha 1$-antichymiotrypsin, ceruloplasmin, haptoglobin, and $\alpha 1$-acid glycoprotein in ponies suffering from acute laminitis.

For this reason, in the case of proteinograms of horses suffering from acute infectious and inflammatory diseases, an increase in the a-globulin subfraction may be due to an increase in acute phase proteins. If so, these proteins may be monitored in order to assess the severity of the disease and may have prognostic value. Acute phase proteins only increase in the case of rapidly progressing inflammatory diseases. This increase is particularly pronounced in the case of inflammation of the large or small intestine, acute diarrhoea, septic arthritis, abscesses and lameness. 
Changes in the serum protein profile are also observed in the case of babesiosis. Equine babesiosis is a disease transmitted by ticks and induced by the protozoa Babesia caballi and Babesia equi. Although horses are considered to be the most susceptible to the disease, it may affect horses, donkeys, their hybrids, and wild equids (Malikides et al. 2000; Okamura et al. 2007). Animals that suffer from the chronic form of the disease may survive many months with no visible symptoms. Symptoms may include constant weight loss and slight anaemia, usually following exertion or a stress situation (Hailat et al. 1997).

Babesiosis is an important disease from an economic perspective as well as in terms of animal health, as it entails substantial losses due to deaths and decreased productivity. Furthermore, equestrian regulations in some countries prohibit symptomatic and asymptomatic seropositive animals from entering the country (Asenzo et al. 2008). Horses with babesiosis often exhibit an increase in total protein concentration, usually due to dehydration and an increase in $\mathrm{y}$-globulins (Kumar et al. 2002).

Hyperproteinaemia in babesiosis is usually the result of dehydration, the main cause of which is considered to be lethargy induced by the disease (Divers 2008). In addition, an elevated concentration of $\mathrm{y}$-globulins causes an increase in the total protein concentration (Radostits et al. 1999). An increased albumin concentration can be explained as a result of dehydration, as no pathological processes involving increased albumin production have been described (Kaneko 1997). It is thought that in order to produce clinical symptoms the serum albumin level must drop below $15.0 \mathrm{~g} / \mathrm{l}$. A decreased albumin concentration in horses with babesiosis is linked to hepatopathy, which may develop during the disease (Colville 2002), and with a state of symptomatic malnutrition (Stockham and Scott 2002). Hypoalbuminemia is usually associated with chronic and prolonged cases. In addition, a change in the albumin concentration is usually associated with a surplus of total protein in the serum, as this is the most abundant protein in the blood of tested animals (Barrera et al. 2010).

The increased concentration of a-globulins is typical for the acute phase because the concentration of the proteins increases immediately after the onset of inflammation or a wound (Stockham and Scott 2002). In horses the a1-globulin concentration is lower than that of a2-globulins, although functionally the differences between them have not been described. These proteins are usually assessed together as alpha-globulins, without indicating subfractions (Sevelius and Andersson 1995; Kaneko 1997).

An increase in the a-globulin fraction occurs more often in horses suffering from various pathologies (Carapeto et al. 2006). Although this increase is caused by inflammatory processes and tissue damage, an elevated $\alpha$-globulin fraction may also be observed in non-inflammatory diseases, e.g. in the case of liver or kidney damage (Kaneko 1997). This may explain the results observed in some horses, because when hepatitis develops an increase may be observed in a1-acid glycoproteins, a1-antitrypsin, haptoglobin and $\alpha 2$-macroglobulin (Sevelius and Andersson 1995). Moreover, in the case of animals with babesiosis, the development of kidney disease is usually due to dehydration and haemoglobinuria through intravascular haemolysis caused by the presence of the parasite. Finally, an increase in the alpha-globulin fraction may be checked by a decrease in the haptoglobin concentration, which is usually observed in animals with the haemolytic anaemia characteristic of this disease (Navarrete and Serrano 1999). 
In the case of babesiosis, defence mechanisms are varied, although the protozoa may activate a cellular immune response (Morris and Johnston 2002). An increase in the $\mathrm{y}$ globulin concentration is linked to immunity activated by infection by the parasites. This occurs mainly in horses with severe hypergammaglobulinemia and liver damage, although the immune response in some animals may cause an increase in immunoglobulins that is too small to be detected by routine electrophoresis techniques (Stockham and Scott 2002).

Goundasheva (2015) examined the electrophoretic profile of serum protein migration in horses subjected to physical exertion following vaccination against flu and equine herpesvirus. The author found changes in the concentration of all proteins in relation to the albumin concentration. This was probably due to haemoconcentration occurring after heavy perspiration during physical exertion, leading to dehydration. According to some authors a change in plasma albumin is not an optimal parameter of dehydration (Lucke and Hall 1980). Stockham (1995) reports that glucocorticosteroids are administered to increase albumin synthesis in order to induce hyperalbuminemia in various species, including horses. Hyperproteinaemia associated with hyperalbuminemia has been observed by other authors (Hanzawa et al. 2000). Administration of EHV 4/1 and vaccination against EIV in horses do not cause an inflammatory reaction. An increase in the total globulin value and the gamma globulin concentration suggested stimulation of the immune system. In revaccinated horses physical exercise affected but did not suppress the immune response. Physical exercise in revaccinated horses has a modifying effect on the serum protein concentration. This is an important factor in monitoring the health condition of vaccinated horses during training and jumping competitions (Goundasheva 2015).

\section{CONCLUSION}

Serum electrophoresis is a common diagnostic laboratory technique in humans and small animals. Nevertheless, despite the fact that it provides useful information on protein fractions, including acute phase proteins which increase immediately after inflammation, and inflammatory diseases occur frequently in horses, serum electrophoresis is not commonly used in equine medicine. Studying changes protein fractions and individual indicators of proteins makes it possible to differentiate diseases even when the total protein concentration, a clinically important symptom, remains unchanged. Serum protein electrophoresis in horses can be recommended as a screening test for qualitative detection of abnormalities in the major proteins and an important supplementation of detailed qualitative and quantitative determination of serum proteins.

\section{REFERENCES}

Alsemgeest S.P., Kalsbeek H.C., Wensing T., Koeman J.P., Edere A.M. van, Gruys E. 1994. Concentrations of serum amyloid-A (SAA) and haptoglobin (HP) as parameters of inflammatory diseases in cattle. Vet. Q. 16, 21-23.

Asenzo G., Wilkowsky S., Barrandeguy M., Mesplet M., Benitez D., Florin-Christensen M. 2008. Development of an indirect ELISA for the diagnosis of equine piroplasmosis. Ann. N Y Acad. Sci. 1149, 235-238. 
Barrera R., Carapeto M.V., Habela M.A. Zaragoza C. 2010. Electrophoretic pattern of serum proteins in horses with babesiosis. Arch. Med. Vet. 42, 173-178.

Bobilewicz D. 2005. Elektroforeza w praktyce laboratoryjnej. Cz. 1. Rozdział elektroforetyczny białek surowicy [Electrophoresis in laboratory practice. Part 1. Serum electrophoresis of serum proteins]. Prz. Med. Lab. 4, 3-6. [in Polish]

Carapeto M.V., Barrera R., Mañe M.C., Zaragoza C. 2006. Serum a-globulin fraction in horses is related to changes in the acute phase proteins. J. Equine Vet. Sci. 26, 120-127.

Colville J. 2002. Blood chemistry, in: Laboratory procedures for veterinary technicians. Ed. C.M. Hendrix. Mosby, St. Louis, USA.

Cray C., Zaias J., Altman N.H. 2009. Acute phase response in animals. A review. Comp. Med. 59, 517-523.

Crisman M.V., Scarratt W.K. 2008. Immunodeficiency disorders in horses. Vet. Clin. North Am. Equine Pract. 24, 299-310.

Divers T.J. 2008. Liver failure: hemolitic anemia, in: Manual of equine emergencies. Eds. J.A. Orsini, T.J. Divers. Philadelphia, USA, Saunders.

Fagliari J.J., McClenahan D., Evanson O.A., Weiss D.J. 1998. Changes in plasma protein concentrations in ponies with experimentally induced alimentary laminitis. Am. J. Vet. Res. 59, 1234-1237.

Gama F.G., Santana A.E., Filho E.C., Nogueira C.A. 2007. Agarose gel electrophoresis of cerebrospinal fluid proteins of dogs after sample concentration using a membrane microconcentrator technique. Vet. Clin. Pathol. 36, 85-88.

Gerou-Ferriani M., McBrearty A.R., Burchmore R.J., Jayawardena K.G., Eckersall P.D., Morris J.S. 2011. Agarose gel serum protein electrophoresis in cats with and without lymphoma and preliminary results of tandem mass fingerprinting analysis. Vet. Clin. Pathol. 40, 159-173.

Giori L., Giordano A., Giudice C., Grieco V., Paltrinieri S. 2011. Performances of different diagnostic tests for feline infectious peritonitis in challenging clinical cases. J. Small Anim. Pract. 52, 152-157.

Giot J.F. 2010. Agarose gel electrophoresis - applications in clinical chemistry. JMB 29, 9-14.

Goundasheva D. 2015. Electrophoretic analysis of serum proteins in strenuously trained horses revaccinated against equine herpes virus 4/1 and equine influenza virus. Vet. Med. Zoot. 69, 18-25.

Grauer G.F. 2005. Canine glomerulonephritis: new thoughts on proteinuria and treatment. J. Small Anim. Pract. 46, 469-478.

Hailat N.Q., Lafi S.Q., Al-Darraji A.M., Al-Ani F.K. 1997. Equine babesiosis associated with strenous exercise: clinical and pathological studies in Jordan. Vet. Parasitol. 69, 1-8.

Hanzawa K., Orihara K., Kubo K., Hiraga A., Yoshida Y., Watanabe S. 2000. Changes of twodimensional electrophoretic patterns of plasma proteins with maximum exercises in young thoroughbred horses. Asian-Aus. J. Anim. Sci. 13, 152-155.

Jania B., Andraszek K. 2016. Application of native agarose gel electrophoresis of serum proteins in veterinary diagnostics. J. Vet. Res. 60, 501-508.

Kaneko J.J. 1997. Serum proteins and the dysproteinemias, in: Clinical biochemistry of domestic animals. Eds. J.J. Kaneko, J.W. Harvey, M. Bruss. San Diego, California, USA, Academic Press.

Keren F.D. 2003. Protein electrophoresis in clinical diagnosis. Oxford University Press Inc.

Kumar S., Malhotra D.V., Nichani A.K. 2002. Identification of immunoreactive polypeptides of Babesia equi parasite during immunization. Vet. Parasitol. 107, 295-301.

Lucke J.N., Hall G.N. 1980. Further studies on the metabolic effects of long distance riding: Golden Horseshoe Ride 1979. Equine Vet. J. 12, 189-192.

Malikides N., Hodgson J.L., Kessell A.E. 2000. Practical clinical pathology, in: Manual of equine practice. Eds. R.J. Rose, D.R. Hodgson. Philadelphia, USA, Saunders.

Morris D.D., Johnston J.K. 2002. Alterations in blood proteins, in: Large animal internal medicine. Ed. B.P. Smith. St. Louis, USA, Mosby. 
Navarrete I., Serrano F.J. 1999. Babesiosis, in: Parasitología veterinaria. Eds. M. Cordero del Campillo, F.A. Vázquez, A.R. Martínez, M.C. Sánchez, S. Hernández, I. Navarrete, P. Diez. Madrid, España, McGraw-Hill Interamericana.

O'Connell X.T., Horita J.T., Kasravi B. 2005. Understanding and interpreting serum protein electrophoresis. Am. Falimy Physic. 71, 105-112.

Okamura M., Yokohama N., Takabatake N., Okubo K., Ikehara Y., Igarashi I. 2007. Modification of host erythrocyte membranes by trypsin and chymotrypsin treatments and effects on the in vitro growth of bovine and equine Babesia parasites. J. Parasitol. 93, 208-211.

Patel R.T., Caceres A., French A.F., McManus P.M. 2005. Multiple myeloma in 16 cats: a retrospective study. Vet. Clin. Pathol. 34, 341-352.

Petersen H.H., Nielsen J.P., Heegaard P.M. 2004. Application of acute phase protein measurements in veterinary clinical chemistry. Vet. Res. 35,163-187.

Radostits O.M., Gay C.C., Blood D.C., Hinchcliff K.W. 1999. Diseases caused by protozoa, in: Veterinary medicine. Eds. Q.M. Radostits, C.C. Gay, D.C. Blood, K.W. Hinchcliff. London, United Kingdom, Saunders.

Riond B., Wenger-Riggenbach B., Hofmann-Lehmann R., Lutz H. 2009. Serum protein concentrations from clinically healthy horses determined by agarose gel electrophoresis. Vet. Clin. Pathol. 38, 73-77.

Sevelius E., Andersson M. 1995. Serum protein electrophoresis as a prognostic marker of chronic liver disease in dogs. Vet. Rec. 137, 663-667.

Stachurska A., Nogaj A., Brodacki A., Nogaj J., Batkowska J. 2014. Genetic distances between horse breeds in Poland estimated according to blood protein polymorphism. Czech. J. Anim. Sci. 6, 257-267.

Stockham S.L. 1995. Interpretation of equine serum biochemical profile results. Vet. Clin. North Am. Equine Pract. 11, 391-414.

Stockham S.L., Scott M.A. 2002. Proteins, in: Fundamentals of veterinary clinical pathology. Eds. S.L. Stockham, M.A. Scott. lowa, USA, lowa State Press.

Taira T., Fujinaga T., Okumura M., Yamashita K., Tsunoda N., Mizuno S. 1992. Equine haptoglobin: isolation, characterization, and the effects of aging, delivery, and inflammation on its serum concentrations. J. Vet. Med. Sci. 54, 424-432.

Thrall M.A., Weiser G., Allison R., Campbell T.W. 2012. Veterinary hematology and clinical chemistry. Ames IA, Wiley-Blackwell.

Yamada O., Tamura K., Yagihara H, Isotani M., Azakami M., Sawada S., Ono K., Washizu T., Bonkobara M. 2005. Light-chain multiple myeloma in a cat. J. Vet. Diag. Invest. 19, 443-447.

\begin{abstract}
The aim of the study was to use serum protein electrophoresis for a preliminary evaluation of the physiological condition of horses and detection of potential diseases. The serum electropherogram of healthy horses is characterized by a lack of a prealbumin zone, and 6 different bands can be observed: albumin, $\alpha 1, \alpha 2, \beta 1, \beta 2$, and $\mathrm{y}$-globulin. Numerous pathological states in horses, including liver diseases, innate or acquired immune deficiencies, enteropathies and nephropathies associated with protein loss, local or systemic infections, cancers, and parasites can cause changes in the albumin fraction and globulin concentration. The serum protein level can also change significantly in the case of equine babesiosis. In the horses tested the serum content of albumins and three globulin fractions with their subfractions were determined. The total protein concentration and the ratio of albumins to total globulins $(\mathrm{A} / \mathrm{G})$ were determined. Serum protein electrophoresis in horses can be recommended as a screening test for qualitative detection of abnormalities in the major proteins and as an important supplement to detailed calculation of serum proteins.
\end{abstract}

